\title{
Who Will Have Health Insurance in the Future? An Updated Projection
}

\author{
Richard A. Young, $M D^{1}$ \\ Jennifer E. DeVoe, MD, DPbil ${ }^{2}$ \\ 'John Peter Smith Hospital FMRP, Fort \\ Worth, Texas \\ ${ }^{2}$ Department of Family Medicine, Oregon \\ Health Sciences University, Portland, \\ Oregon
}

\begin{abstract}
The passage of the 2010 Patient Protection and Affordable Care Act (PPACA) in the United States put the issues of health care reform and health care costs back in the national spotlight. DeVoe and colleagues previously estimated that the cost of a family health insurance premium would equal the median household income by the year 2025. A slowdown in health care spending tied to the recent economic downturn and the passage of the PPACA occurred after this model was published. In this updated model, we estimate that this threshold will be crossed in 2033, and under favorable assumptions the PPACA may extend this date only to 2037. Continuing to make incremental changes in US health policy will likely not bend the cost curve, which has eluded policy makers for the past 50 years. Private health insurance will become increasingly unaffordable to low-to-middleincome Americans unless major changes are made in the US health care system.
\end{abstract}

Ann Fam Med 2012;10:156-162. doi:10.1370/afm.1348.

\section{INTRODUCTION}

$\mathrm{H}$

ealth care inflation slowed during the managed care era of the late 1990s, but it rose sharply after the public backlash against managed care caused many employers to abandon that model. The sharp increase in health insurance premium inflation that started around 1999 was coupled with declining inflation in household incomes. This mismatch in rate trends is displayed in Figure 1. As has historically been the case when health reform policies are being debated by the United States Congress, the annual rate of inflation for health insurance premiums in 2009 to 2010 slowed to the lowest level since the late 1990 s. $^{1-3}$ Despite this slowing, the annual inflation rate of health insurance premiums still outpaced US household earnings, which stagnated from 2008 to 2011 and included an absolute reduction in average household income from $\$ 50,300$ in 2008 to $\$ 49,800$ in 2009 . ${ }^{4}$

\section{THE PPACA}

The year 2010 marked the historic passage of the Patient Protection and Affordable Care Act (PPACA), and it also saw the number of persons without health insurance in the United States rise to a historic high of 50.7 million people ${ }^{5}$ after 5 million Americans lost employment-based health insurance in the 2007-2009 recession. ${ }^{6}$ It is ironic that uninsurance rates rose on the heels of the PPACA, which was intended to reduce the numbers of uninsured. Most provisions in the PPACA will be implemented over time, with some not due to take effect until 2014, not soon enough for the millions of Americans who lost jobs and associated health care benefits in 2010.

The PPACA kept intact an insurance-based financing system in which the insurance companies that adjudicate claims and provide some care monitoring and oversight are separated from the entities that deliver the care, such as physicians, hospitals, and ancillary services. Although the 


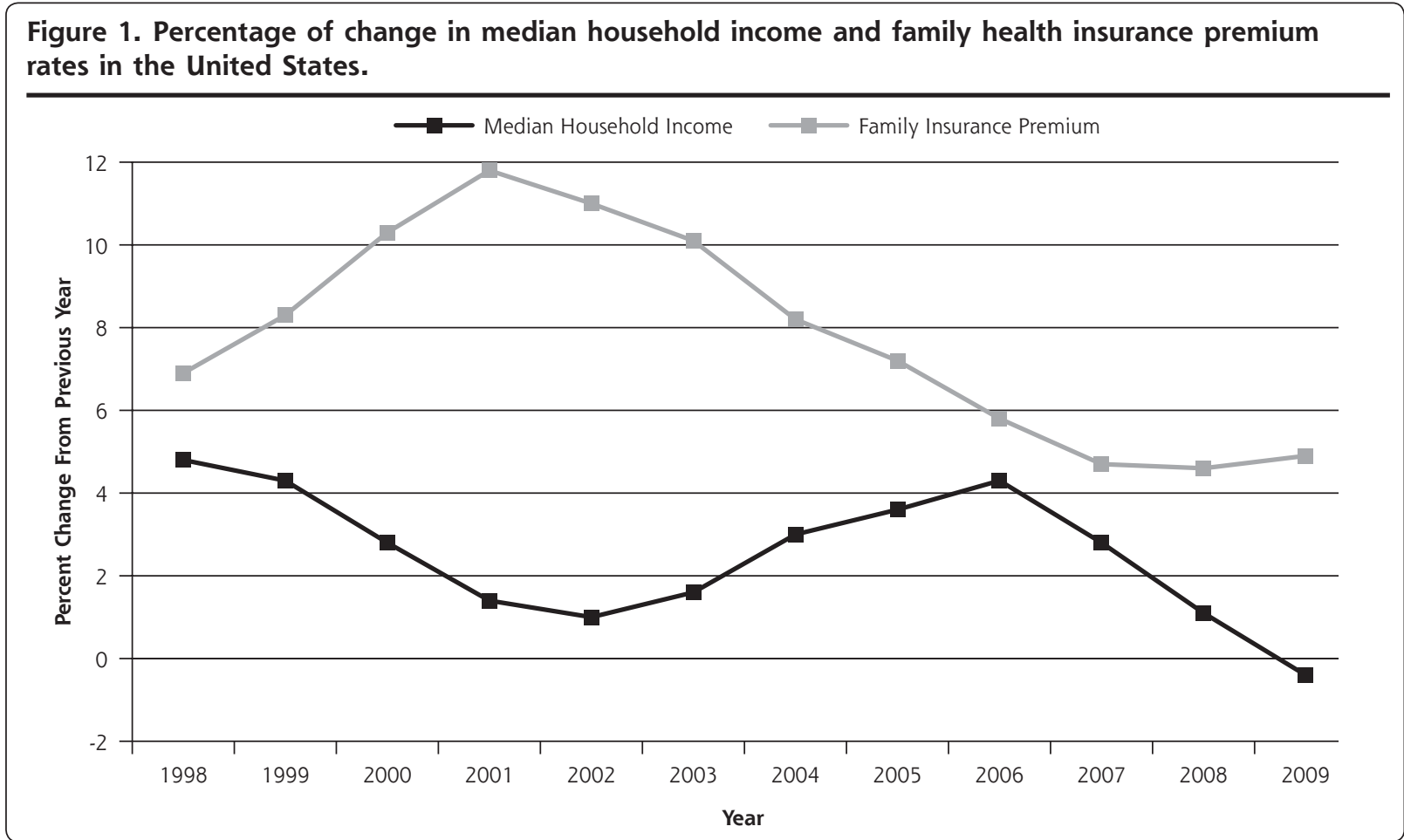

PPACA set some basic parameters on required benefits for insurers wishing to participate in state exchange programs, it preserved the autonomy of private insurers to set rates and to determine cost-sharing amounts (ie, deductibles, co-payments, and lifetime limits).

In 2005, DeVoe et al highlighted the mismatch between rising health insurance costs and stagnant household earnings by projecting that a family health insurance premium would equal the average US family's income by the year 2025. ${ }^{7}$ Given that these 2005 projections may have captured the period when premium rates and household earnings were most disproportionate, the passage of the PPACA, and the recent slowing of health insurance and wage increases, we updated this projection.

Using methods similar to those used by DeVoe et al with data from the Medical Expenditure Panel Survey $(\mathrm{MEPS})^{8}$ and the US Census Bureau, ${ }^{4,9}$ we developed an updated model of insurance premium cost and household income projections. The model presented in Figure 2 includes actual premiums and income figures from 2000 to 2009 and projected trends from 2010 to 2040. From 2000 to 2009, the average annual increase in insurance premiums was $8.0 \%$; household incomes rose an average of $2.1 \%$.

If health insurance premiums and national wages continue to grow at recent rates and the US health system makes no major structural changes, the average cost of a family health insurance premium will equal $50 \%$ of the household income by the year 2021, and surpass the average household income by the year 2033. If out-of-pocket costs are added to the premium costs, the $50 \%$ threshold is crossed by 2018 and exceeds household income by 2030 .

As most workers do not currently pay the entire cost of their premiums, we believed it was also important to include another projection: the total cost of health care for a family. For this estimate (Figure 3), we calculated the average amount an employee pays for a family health insurance premium plus out-ofpocket family health care expenses. Because the MEPS database does not provide explicit out-of-pocket expense data for privately-insured families, MEPS premium data were combined with out-of-pocket estimates obtained from the Milliman Medical Index (outof-pocket costs were estimated as a percentage of the total premium).$^{10}$

Without major structural changes in the US health care system, the employee contribution to a family premium plus out-of-pocket costs will comprise onehalf the household income by 2031 and total income by 2042 . Rising health care costs remain at the core of this unsustainable rise in insurance premiums. ${ }^{10-12}$

\section{PPACA COST MODELING}

Experts disagree whether the PPACA will raise private insurance costs, ${ }^{13,14}$ not have much effect, ${ }^{15,16}$ or lower 
Figure 2. Projected annual family health insurance premium costs and average household income in the United States.

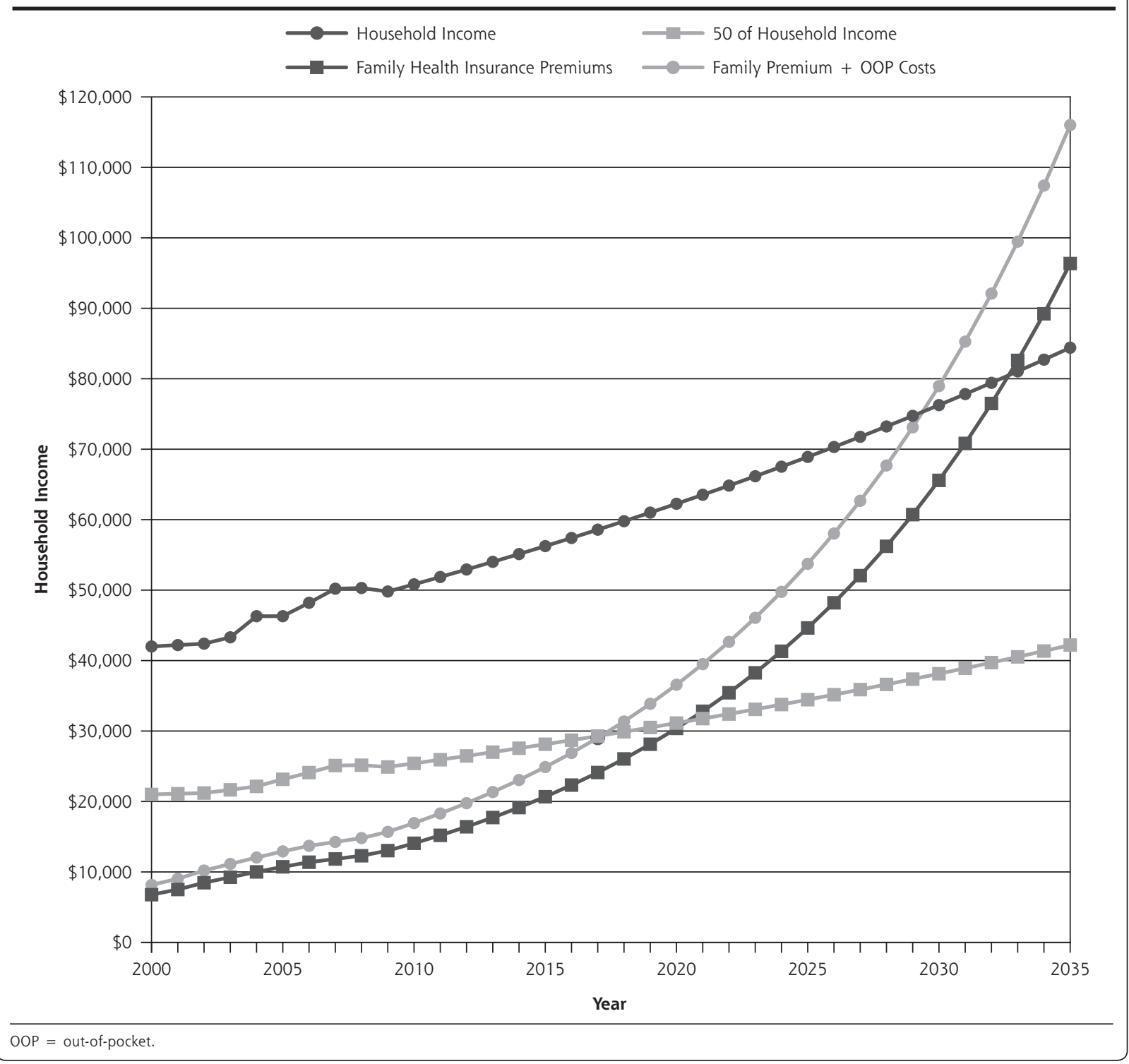

costs. ${ }^{17,18}$ For our estimates, we included 2 models: no effect on the annual increase in health insurance premium inflation compared with the experience of the last 10 years $(8.0 \%)$, and one that assumes a modestly favorable impact of the PPACA on reducing the growth rate in the cost of private insurance $(7.0 \%)$ (Figure 4). ${ }^{17,18}$ Assuming the PPACA actually slows cost growth, this threshold of insurance premiums exceeding household income is delayed only by 4 years.

\section{THE COST CURVE IS BARELY BENDING}

DeVoe et al estimated that the cost of insurance premiums would surpass household income by $2025^{7}$; our new projection inches it out to 2033. On first glance, this change in the projection might be perceived as progress, which is due in part to a recent slowdown in the rate of premium increases from 2003 to 2009. During that same period, however, employee contributions to insurance premiums and out-of-pocket expenses have grown faster than overall premium costs, suggesting that insurers have slowed the rate of growth in premiums by shifting more costs onto patients. Even though patients no longer face double-digit increases in insurance premiums each year, they now pay higher deductibles and co-payments and receive fewer covered services. ${ }^{19,20}$ In the 2010 Kaiser Family Foundation and Health Research and Educational Trust employer 


\section{Figure 3. Projected annual family health care costs (premium contribution plus out-of-pocket costs) and average household income in the United States.}

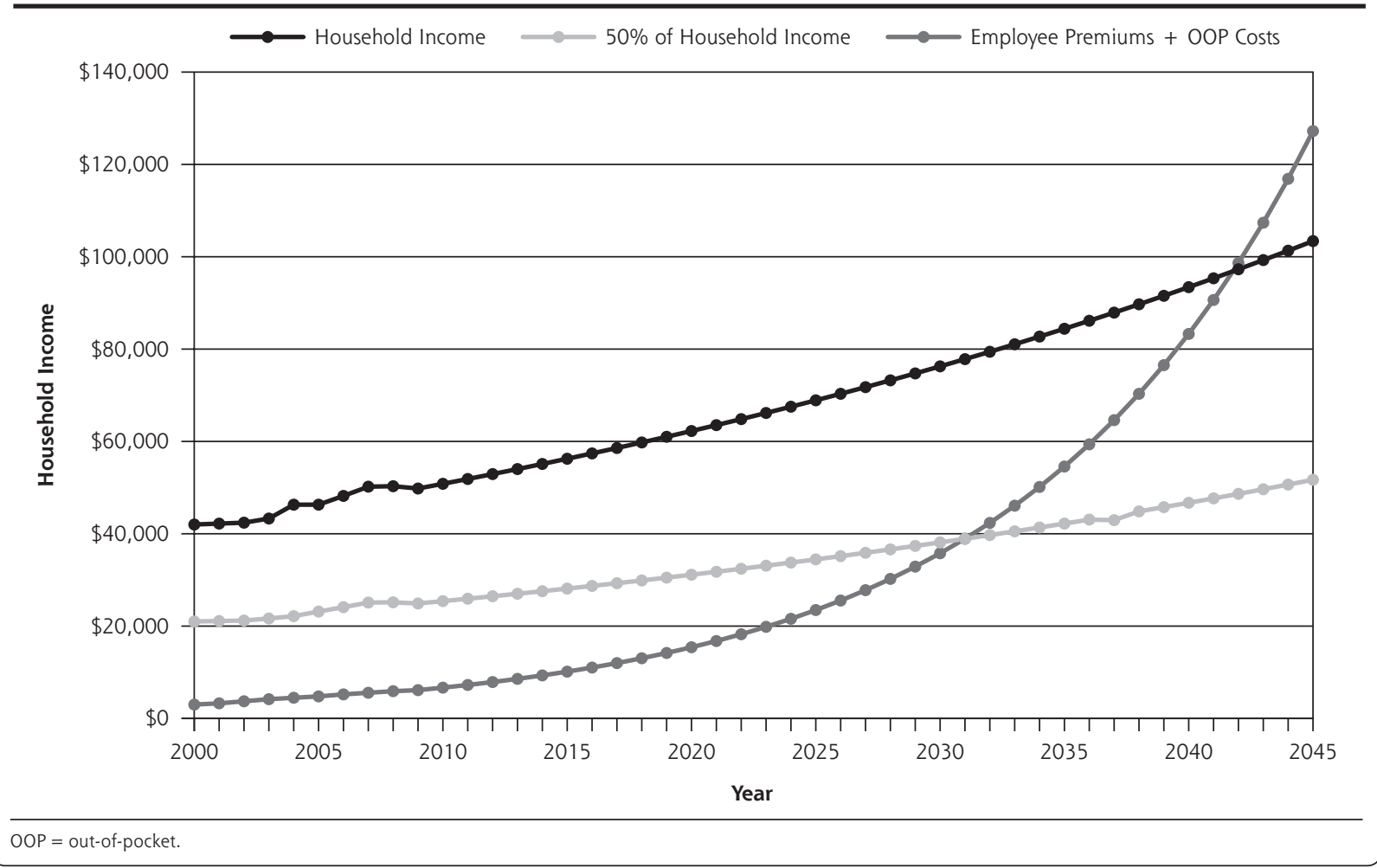

survey, $30 \%$ of employers reported having reduced the scope of health benefits or increased cost sharing, and $23 \%$ increased the share of the premium a worker has to pay. Among large firms (200 or more workers), 38\% reported reducing the scope of benefits or increasing cost sharing, up from $22 \%$ in 2009 , whereas $36 \%$ reported increasing their workers' premium share, up from $22 \%$ in 2009. ${ }^{19}$

Health care continues to comprise a growing portion of the total US economy. It has risen from 13.7\% of gross domestic product (GDP) in 2000 to $17.3 \%$ of GDP in 2010. ${ }^{2}$ From 1960 to 1999, the growth of national health care expenditures exceeded the GDP by $2.4 \%$ per year. ${ }^{12}$ This same $2.4 \%$ differential occurred from 2000 to $2009 . .^{21,22}$ If health care costs continue to rise at current unsustainable rates, it is doubtful that affordable insurance coverage will be available for low- to middle-income Americans in the near future. Further, our model did not include the taxes paid by American workers each year to finance Medicare and Medicaid-nearly $\$ 900$ billion in 2009-which may increase with the PPACA. ${ }^{23}$

It is unlikely that our projections will reach the crossing point for low to average wage earners, meaning where more is actually spent on a family health insurance premium than is earned in house- hold income. It seems more likely that employers will increasingly move to defined contributions, thus limiting their contribution to their employees' health care costs. A recent survey by the National Business Group on Health found that most large employers plan to require employees to contribute a higher percentage of health care premium costs in $2012 .{ }^{24}$ Ultimately many employees will conclude that health insurance is unaffordable, and they will abandon it all together. Perhaps, some workers in this situation will qualify for Medicaid under the PPACA, but this insurer switch does nothing to mitigate the underlying health care inflation rate that makes insurance increasingly unaffordable.

The health care system is complex and adaptive, so it is possible that other changes will occur to avoid a complete meltdown of the system. Accountable care organizations may squeeze out some efficiencies, though at this time it is merely a hope. Increased cost sharing might change some patient expectations and behaviors. Empowering consumers to choose (and pay for) services might also increase price transparency, especially for expensive nonemergent services, such as outpatient magnetic resonance imaging. Health care consumerism has limits, however, because one cannot shop around for surgeons and hospitals when one has appendicitis. 
Figure 4. Family insurance premiums with and without PPACA assumptions of cost savings.

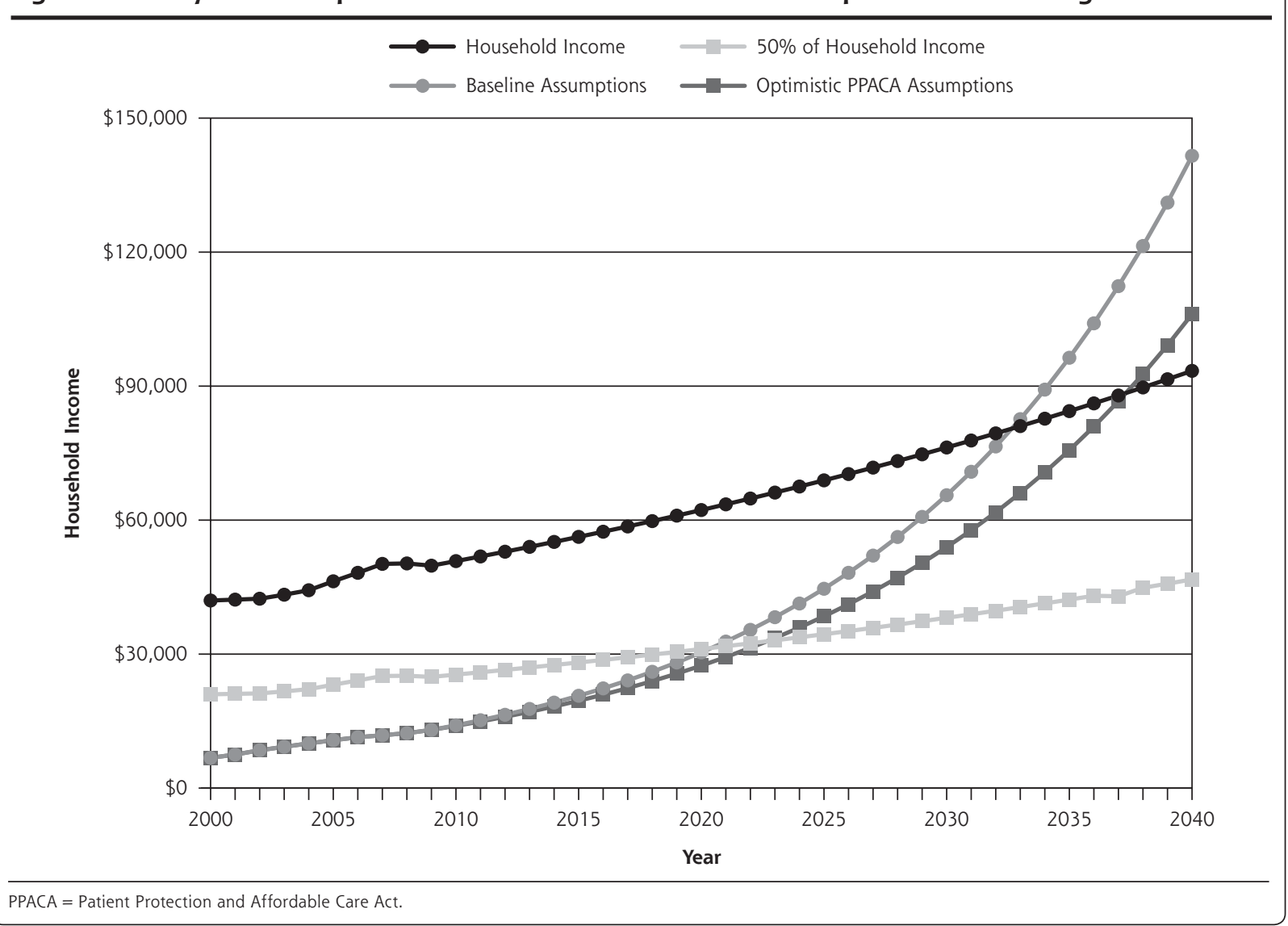

\section{THE TIPPING POINT-HOW DO WE BREAK THE COST CURVE?}

What will it take for Americans to face reality? It has been observed that expensive US health care increases production costs and makes American manufactured goods less competitive, which results in lower wages and fewer jobs in the manufacturing industry. For example in 2006, General Motors' spent $\$ 1,500$ more than Toyota in health care costs per car. ${ }^{25,26}$ Other observers have noted that the American health care industry has continued to grow over the past decadeas measured by its percentage of the GDP and overall employment in the industry-while other industries have declined..$^{27,28}$ Although job growth in the health care sector appeals to some planners, others believe these jobs do not have the economic multiplier effect observed in other industries. ${ }^{28}$ We cannot grow a vibrant economy by repeatedly performing scanning on each other. It is also well-known that the United States spends more on health care costs than any other country in the world but has worse health outcomes than all other developed nations. ${ }^{29}$ This great American health care irony continues to worsen. It's beyond the scope of this essay to list all of the reforms required to create a vastly more affordable health care system, but we offer a few thoughts.

Finding ways to reduce the administrative overhead of US health care could yield cost savings without compromising quality. ${ }^{30,31}$ This overhead often includes profit for US insurance companies not paid in many other developed countries. For example, Switzerland has dozens of insurance companies competing for patients, but they are not allowed to profit from the primary health insurance product, only the supplemental policies. ${ }^{32}$ The recent Dutch experience in fostering competition between insurers, however, has not led to a reduction in the rate of growth of health care expenditures. ${ }^{33}$ Removing all mechanisms to make financial profit from the health care industry might move United States closer to a sustainable system in the future.

Primary care remains an inadequately supported component of the US health care system in spite of the mountain of data showing areas with more primary care physicians have better population health at a lower cost. ${ }^{29,34}$ Perhaps the patient-centered medical home $(\mathrm{PCMH})$ movement can make inroads in this area. ${ }^{35}$ Recent PCMH demonstration projects have 
shown reduced costs and improved quality in health care systems that increased support for primary care through PCMH approaches. ${ }^{36}$ Even so, the evidence for the impact of primary care in reducing costs existed long before its rebranding as the $\mathrm{PCMH} .{ }^{37-39}$

The tipping point may come when patients and physicians realize that we cannot provide all possible services to all people, no matter how rare the benefit or expensive the service. The recent approval by Medicare of the prostate cancer drug sipuleucel-T (Provenge), which will cost an estimated $\$ 93,000$ for treatment to increase life expectancy by 4 months, is an example of a very expensive service contributing to health care inflation. Achieving balance will also require accepting that more aggressive care does not always mean better care..$^{34,40-45}$

For the sake of our children and grandchildren, let's hope that we find the courage to have the difficult discussions now and make the right choices to achieve sustainability. None of the efforts to tweak health care costs using payment changes has bent the cost curve during the last 50 years. America needs a deeper discussion of the very role and importance of the health care system in our lives, possibly including new expectations of the doctor-patient relationship. Alternatively, we can choose to continue along the current path, which will leave the difficult decisions to our children and grandchildren, who will be crushed by the debt created by the excesses of this generation.

To read or post commentaries in response to this article, see it online at http://www.annfammed.org/content/10/2/156.

Key words: Health insurance; health policy; health policy research; health care economics and organizations; health expenditures

Submitted June 8, 2011; submitted, revised, August 26, 2011; accepted September 13, 2011.

Acknowledgments: The authors thank the Milliman Medical Index research team for helping us better understand their methodology.

\section{References}

1. Borger C, Smith S, Truffer $C$, et al. Health spending projections through 2015: changes on the horizon. Health Aff (Millwood). 2006; 25(2):w61-w73.

2. Truffer CJ, Keehan S, Smith S, et al. Health spending projections through 2019: the recession's impact continues. Health Aff (Millwood). 2010;29(3):522-529.

3. Blumenthal D. Employer-sponsored insurance-riding the health care tiger. N Engl J Med. 2006;355(2):195-202.

4. US Census Bureau. Median Household Income by State: 1984 to 2009. http://www.census.gov/hhes/www/income/data/historical/ household/H08_2009.xls. Accessed Apr 7, 2011.

5. Robert Wood Johnson Foundation. State of the States.Feb 2011. http://www.rwjf.org/files/research/71835report.pdf. Accessed Apr 7, 2011.
6. Holahan J. The 2007-09 recession and health insurance coverage. Health Aff (Millwood). 2011;30(1):145-152.

7. DeVoe J, Dodoo M, Phillips RJ, Green L. Who will have health insurance in the year 2025? Robert Graham Center. http://www.grahamcenter.org/online/graham/home/publications/onepagers/2005/ op40-insurance-2025.html. Accessed Jun 16, 2009.

8. Medical Expenditure Panel Survey. http://www.meps.ahrq.gov/ mepsweb/. Accessed May 25, 2011.

9. US Census Bureau. National Health Expenditures-Summary. 1960 to 2006, and Projections, 2007 to 2017. http://www.census.gov/ compendia/statab/tables/09s0124.pdf.

10. Engdahl-Johnson J. Mayne L. 2010 Milliman Medical Index. 2010 http://publications. milliman.com/periodicals/mmi/pdfs/millimanmedical-index-2010.pdf. Accessed Apr 9, 2011.

11. Anderson GF, Reinhardt UE, Hussey PS, Petrosyan V. It's the prices, stupid: why the United States is so different from other countries. Health Aff (Millwood). 2003;22(3):89-105.

12. Reinhardt UE, Hussey PS, Anderson GFUS. U.S. health care spending in an international context. Health Aff (Millwood). 2004;23(3):10-25.

13. Howard P. The impact of the Affordable Care Act on the economy, employers, and the workforce. 2011. http://www.medicalprogress today.com/spotlight/spotlight_indarchive.php?id=1887. Accessed Apr 21, 2011.

14. Foster R. Estimated financial effects of the "Patient Protection and Affordable Care Act," as amended. April 22, 2010. http://graphics8 .nytimes.com/packages/pdf/health/oactmemo1.pdf. Accessed Jun 2, 2011.

15. Pizer S, Frakt A, lezzoni L. The effect of health reform on public and private insurance in the long run. 2011. http://papers.ssrn.com/ sol3/papers.cfm?abstract_id=1782210. Accessed Apr 21, 2011.

16. Gruber J. Massachusetts points the way to successful health care reform. J Policy Anal Manage. 2010. http://onlinelibrary.wiley.com/ doi/10.1002/pam.20551/full. Accessed Apr 21, 2011.

17. Cutler DM, Davis K, Stremikis K. The impact of health reform on health system spending. The Commonwealth Fund. 2010. http:// www.commonwealthfund.org/ /media/Files/Publications/lssue\%20 Brief/2010/May/1405_Cutler_impact_hlt_reform_on_hlt_sys_ spending_ib_v4.pdf. Accessed Apr 21, 2011.

18. Congressional Budget Office. Letter to the Honorable Evan Bayh Nov 30, 2009 Washington, DC: CBO:2009. http://www.cbo.gov/ sites/default/files/cbofiles/ftpdocs/107xx/doc10781/11-30-premiums .pdf.

19. The Kaiser Family Foundation and Health Research \& Educational Trust. Employer health benefits: 2010 summary of findings. http:// ehbs.kff.org/pdf/2010/8086.pdf.

20. Claxton G, DiJulio B, Whitmore $\mathrm{H}$, et al. Health benefits in 2010: premiums rise modestly, workers pay more toward coverage. Health Aff (Millwood). 2010;29(10):1942-1950.

21. Bureau of Economic Analysis. National economic accounts, frequently requested NIPA tables. http://www.bea.gov/national/ nipaweb/SelectTable.asp?Popular=Y. Accessed May 30, 2011.

22. Centers for Medicare and Medicaid Services. National health expenditures aggregate. https://www.cms.gov/NationalHealth ExpendData/downloads/tables.pdf. Accessed May 30, 2011.

23. Centers for Medicare and Medicaid Services. National health expenditures 2009 highlights. http://www.cms.gov/NationalHealth ExpendData/downloads/highlights.pdf. Accessed Apr 9, 2011.

24. Bureau of National Affairs. Employees to pay higher share of health costs. Aug 23, 2011. http://www.bna.com/employees-pay-highern12884903185/. Accessed Aug 26, 2011.

25. Griswold DG. M's woes homemade, not imported. Cato Institute. Jun 26, 2005. http://www.freetrade.org/node/378.

26. McAlinden S. Boom gone to bust? The CAW/UAW labor deals in light of market restructuring. http://auto21.ca/uploads/2008_Conference/ Outlook_MCALINDEN_040608.pdf. Accessed Apr 1, 2009. 
27. Mandel M, Weber J. What's really propping up the economy? Sep 25, 2006. http://www.businessweek.com/magazine/content/06_39/ b4002001.htm. Accessed Aug 23, 2011.

28. White C, Ginsburg P. Working at cross purposes: health care expansions may jumpstart local economies but fuel nation's fiscal woes. Aug 2011. http://hschange.org/CONTENT/1228/. Accessed Aug 23, 2011.

29. Starfield B, Shi L, Macinko J. Contribution of primary care to health systems and health. Milbank Q. 2005;83(3):457-502.

30. Himmelstein DU, Woolhandler S, Wolfe SM. Administrative waste in the U.S. health care system in 2003: the cost to the nation, the states, and the District of Columbia, with state-specific estimates of potential savings. Int J Health Serv. 2004;34(1):79-86.

31. Woolhandler S, Himmelstein DU, Lewontin JP. Administrative costs in U.S. hospitals. N Engl J Med. 1993;329(6):400-403.

32. Reinhardt UE. The Swiss health system: regulated competition without managed care. JAMA. 2004;292(10):1227-1231.

33. Okma KG, Marmor TR, Oberlander J. Managed competition for Medicare? Sobering lessons from The Netherlands. $N$ Engl J Med. 2011;365(4):287-289.

34. Baicker K, Chandra A. Medicare spending, the physician workforce, and beneficiaries' quality of care. Health Aff (Millwood). 2004;(Suppl Web Exclusives):W/4-184-97.

35. American Academy of Family Physicians (AAFP), American Academy of Pediatrics (AAP), American College of Physicians (ACP), (AOA) AOA. Joint principles of the Patient-Centered Medical Home. Feb 2007. http://www.aafp.org/online/etc/medialib/aafp_org/documents /policy/fed/jointprinciplespcmh0207.Par.0001.File.dat/022107 medicalhome.pdf. Accessed Feb 22, 2011.

36. Grumbach K, Grundy P. Outcomes of implementing patient centered medical home interventions: a review of the evidence from prospective evaluation studies in the United States.Nov 16, 2010. http://www.pcpcc.net/files/evidence_outcomes_in_pcmh.pdf. Accessed Aug 18, 2011
37. Greenfield S, Nelson EC, Zubkoff M, et al. Variations in resource utilization among medical specialties and systems of care. Results from the medical outcomes study. JAMA. 1992;267(12):1624-1630.

38. Greenfield S, Rogers W, Mangotich M, Carney MF, Tarlov AR. Outcomes of patients with hypertension and non-insulin dependent diabetes mellitus treated by different systems and specialties. Results from the medical outcomes study. JAMA. 1995;274(18):1436-1444.

39. McCarthy D. Quality matters case study: quadmed-transforming employer-sponsored health care through workplace primary care and wellness programs. Sep/Oct 2009. http://www.commonwealthfund.org/Newsletters/Quality-Matters/2009/September-October-2009/Case-Study.aspx. Accessed Aug 23, 2011.

40. Fisher ES, Bynum JP, Skinner JS. Slowing the growth of health care costs-lessons from regional variation. N Engl J Med. 2009;360(9): 849-852.

41. Fisher ES, Wennberg DE, Stukel TA, Gottlieb DJ, Lucas FL, Pinder EL. The implications of regional variations in Medicare spending. Part 2: health outcomes and satisfaction with care. Ann Intern Med. 2003;138(4):288-298.

42. Fisher ES, Wennberg DE, Stukel TA, Gottlieb DJ, Lucas FL, Pinder EL. The implications of regional variations in Medicare spending. Part 1: the content, quality, and accessibility of care. Ann Intern Med. 2003;138(4):273-287.

43. Goodman DC, Grumbach K. Does having more physicians lead to better health system performance? JAMA. 2008;299(3):335-337.

44. Wennberg DE, Fisher ES, Goodman DC, Skinner JS, Bronner KK, Sharp SM. Taking care of patients with severe chronic disease: the Dartmouth atlas of health care 2008. The Dartmouth Institute for Health Policy and Clinical Practice Center for Health Policy Research. 2008. http://www.dartmouth.edu/ jskinner/documents/ 2008_Chronic_Care_Atlas.pdf. Accessed May 2, 2009.

45. Wennberg JE, Fisher ES, Baker L, Sharp SM, Bronner KK. Evaluating the efficiency of california providers in caring for patients with chronic illnesses. Health Aff (Millwood). 2005;(Suppl Web Exclusives): W5-526-543. 